\title{
Implications of sustainability for the United States light-duty transportation sector
}

Chris Gearhart, National Renewable Energy Laboratory, Transportation and Hydrogen System Center, Golden, C0 80401, USA

Address all correspondence to Chris Gearhart at chris.gearhart@nrel.gov (Received 28 January 2016; accepted 29 June 2016)

\section{ABSTRACT}

\section{This paper reviews existing literature to assess the consensus of the scientific and engineering communities concerning the potential for the United} States' light-duty transportation sector to meet a goal of $80 \%$ reduction in vehicle emissions and examine what it will take to meet this target.

Climate change is a problem that must be solved. The primary cause of this problem is burning of fossil fuels to generate energy. A dramatic reduction in carbon emissions must happen soon, and a significant fraction of this reduction must come from the transportation sector. This paper reviews existing literature to assess the consensus of the scientific and engineering communities concerning the potential for the United States' light-duty transportation sector to meet a goal of $80 \%$ reduction in vehicle emissions and examine what it will take to meet this target. It is unlikely that reducing energy consumption in just vehicles with gasoline-based internal combustion drivetrains will be sufficient to meet GHG emission-reduction targets. This paper explores what additional benefits are possible through the adoption of alternative energy sources, looking at three possible on-vehicle energy carriers: carbon-based fuels, hydrogen, and batteries.

\section{DISCUSSION POINTS}

- This paper assumes that greenhouse gas (GHG) reduction required by the light-duty transportation sector will be the same as the overall GHG reduction target. It may be that different sectors have different reduction targets resulting in an overall $80 \%$ reduction. This paper does not address this point.

- One implication of this paper is that the country will need a large shift to low-carbon fuels and energy sources. This paper does not address the cost of such a shift. This is a big deal that needs to be discussed but I choose not to try to cover it in this paper. My goal was to say, if we are serious about an $80 \%$ reduction this is what it means.

- This paper sets a GHG target based on 2050 vehicle kilometers traveled (VKT) projections. This is a very uncertain number and changes from year to year. Although the exact number calculated in this article will change with changes in this projection, the intent of this article is to give an order-of-magnitude picture of the sustainability problem in light-duty transportation. This overall picture does not change with year-to-year adjustment of businessas-usual VKT projections.

- Connectivity and automation have the potential to radically change VKT. We address this qualitatively in the last section of this paper, but acknowledge that rapid changes in this space over the next several decades could happen.

\section{Introduction}

There is broad scientific consensus that global temperatures are increasing due to anthropogenic emissions of greenhouse gases (GHGs). ${ }^{1,2}$ In the United States, the transportation sector accounts for $28 \%$ of the total energy consumed and $72 \%$ of petroleum usage. This accounts for about a third of the United States' GHG emissions. ${ }^{3}$ Light-duty vehicles in the United States were responsible for the equivalent of 1514 million metric tons (MMTs) of carbon dioxide $\left(\mathrm{CO}_{2}\right)$ GHG emissions in 2005. 4,5 To mitigate the worst impacts of climate change, global GHG emissions must be reduced by about $80 \%$ by $2050 .{ }^{6}$ The United States has developed 2020 GHG emissions targets consistent with these findings. ${ }^{7}$

This paper reviews the existing literature to assess the consensus of the scientific and engineering community concerning the potential for the United States' light-duty transportation sector to meet these targets. It is taken as a given that climate change is a problem that must be solved and that the cause of this problem is burning fossil fuels to generate energy. A dramatic reduction in carbon emissions must happen soon, and a significant fraction of this reduction must come from the transportation sector. This paper will not argue about what the fair share is for emission reductions in the light-duty transportation sector. Instead, it assumes that the reduction goal for light-duty vehicle emissions is also $\mathbf{8 0 \%}$, and asks the question, "what does it take to meet this or any target?". 
A number of reports have been written on the potential of future technology to meet future GHG emissions targets. ${ }^{4,8-14}$ A joint report by the National Renewable Energy Laboratory (NREL) and the U.S. Department of Energy (DOE) shows scenarios by which very deep GHG reductions, $80-100 \%$, could be possible by $2050 .{ }^{10}$ This report builds off the earlier NREL-led Transportation Energy Futures studies. ${ }^{9,14}$ The National Research Council has also issued a number of reports on the potential to make significant reductions in fuel consumption and transition to alternative energy transportation. ${ }^{4,11,12}$

The potential for reducing energy consumption in vehicles with gasoline-based internal combustion drivetrains is investigated first. It will be shown that it is unlikely that these efforts alone will be sufficient to meet GHG emission-reduction targets. Next, the report will look at what additional benefits are possible through the adoption of alternative energy sources. These will be examined in the context of three possible on-vehicle energy carriers: carbon-based fuels, hydrogen, and batteries. Each of these has associated potential for additional drivetrainbased reductions in energy intensity (EI) and corresponding carbon intensity (CI).

With a combination of drivetrain efficiency improvement and alternative energy sources, it is possible to meet the GHG reduction targets, but a difficult and capital-intensive transformation of the energy generation systems will be required, making it a challenge to meet the goals in the necessary timeframe. The last section of this report looks at what transformation, enabled by ever-increasing levels of connectivity, may be possible to more quickly change the demand for transportation.

\section{Vehicle-level targets}

In this section, the $80 \%$ national-level GHG reduction targets are brought down to the vehicle level, using as a baseline the 2005 light-duty GHG emissions of $1514 \mathrm{MMT} \mathrm{CO}_{2}$ equivalent. An $80 \%$ reduction from this number results in a 2050 budget of 303 MMT. $^{5}$

The Energy Information Agency projects that light-duty vehicle travel in the United States will reach 5.7 trillion kilometers per year in $2040 .{ }^{3}$ Its projection does not extend out to 2050 , but the trend it predicts is very linear, with a growth rate of about 57 billion kilometers per year. For the purposes of setting a 2050 GHG emissions-per-unit distance-driven target, it is assumed that vehicle-kilometers traveled (VKT) continue to increase at this rate for the decade between 2040 and 2050. This provides a baseline estimate for VKT in 2050 of 6.3 trillion kilometers. Dividing the GHG budget allowable in 2050 with the projected VKT gives a wells-to-wheels (WTW) GHG emissions target of $48 \mathrm{~g} / \mathrm{km}$.

The objective, then, is to identify sets of technologies that can achieve this goal by 2050. A variety of WTW analyses have been performed for light-duty vehicles. ${ }^{15-17}$ In general, these analyses show that there are potential technology pathways to $48 \mathrm{~g} / \mathrm{km}$. The identified solutions generally fall into one of three different powertrain pathways: battery electric vehicles (BEVs) powered by low-carbon electricity, hydrogen fuel cell vehicles fueled by low-carbon hydrogen, and internal combustion engines (ICEs) fueled with biofuels.

Looking at the results of the WTW analyses, it can be difficult to tell whether the GHG emission numbers are due to the energy consumption of the vehicles or the carbon content of the energy source powering the vehicles. To get more insight into the nature of technologies needed to get achieve the desired GHG emission rates, it is useful to separate WTW emissions into vehicle and fuels components. This is done using a generalized Kaya identity, ${ }^{18}$ which factors WTW emissions into the EI of the vehicle and the CI of the fuel. The WTW emission is the product of these two numbers.

$$
G=\mathrm{EI} \times \mathrm{CI} .
$$

In this expression, EI is amount of energy on average that must be delivered to the vehicle per unit distance the vehicle travels in units of kilowatt-hours per kilometer. The CI is the total amount of GHG emissions emitted to deliver a unit of energy to the vehicle. This includes tail-pipe emissions on the vehicle as well as upstream emissions, expressed in units of grams $\mathrm{CO}_{2}$ equivalent per kilowatt-hour.

Plotted on a graph of EI versus CI, any WTW emissions target will be a hyperbola. Figure 1 shows a plot for a target of $48 \mathrm{~g} / \mathrm{km}$. In this figure, the vertical axis is EI and the horizontal axis is CI. Moving down and to the left of this graph, vehicles become more efficient, and energy sources become more sustainable.

To understand the magnitude of this target, the current status of light-duty vehicles in the United States must be known. In this figure, the 2009 average EI and CI of light-duty vehicles in the United States are also plotted, shown as three crosses. The lower cross represents light-duty cars with an average fuel economy of 23.5 miles per gallon. The top cross represents light-duty trucks with an average of 17.3 miles per gallon. The middle cross is the average of these two weighted by total VKT. ${ }^{19}$ These have been converted to kilowatt-hours per kilometer using the conversion factor $33.7 \mathrm{~kW} \mathrm{~h}$ /gallon of gasoline equivalent (gge). ${ }^{20}$ All three are plotted at the $\mathrm{CI}$ of gasoline, $332 \mathrm{~g} \mathrm{CO}_{2}$ per $\mathrm{kW} \mathrm{h} .^{4}$

In the rest of this paper, the potential to reach $48 \mathrm{~g} / \mathrm{km}$ is next reviewed in three steps. First, the potential to reduce vehicle EI is examined; second, the potential to reduce the CI of vehicle energy sources is examined; and third, the impacts of connectivity and automation on the evolution of the transportation system are examined. This has the potential to improve the effectiveness of the transportation system in general. The improvement can take on many forms that could impact CI, EI, and VKT.

It should be noted here that there is a significant time lag between the development of a technology and deployment of this technology in sufficient volume to influence fleet averages. This is because it takes a significant amount of time to turn over the vehicle fleet.

Note that in the summary of WTW analysis reported above, 2035 technology estimates are targeted rather than 2050 technology estimates. The targets for 2035 technology are used because of the time it takes to turn over the vehicle fleet. The light-duty fleet in the United States is roughly 240 million 


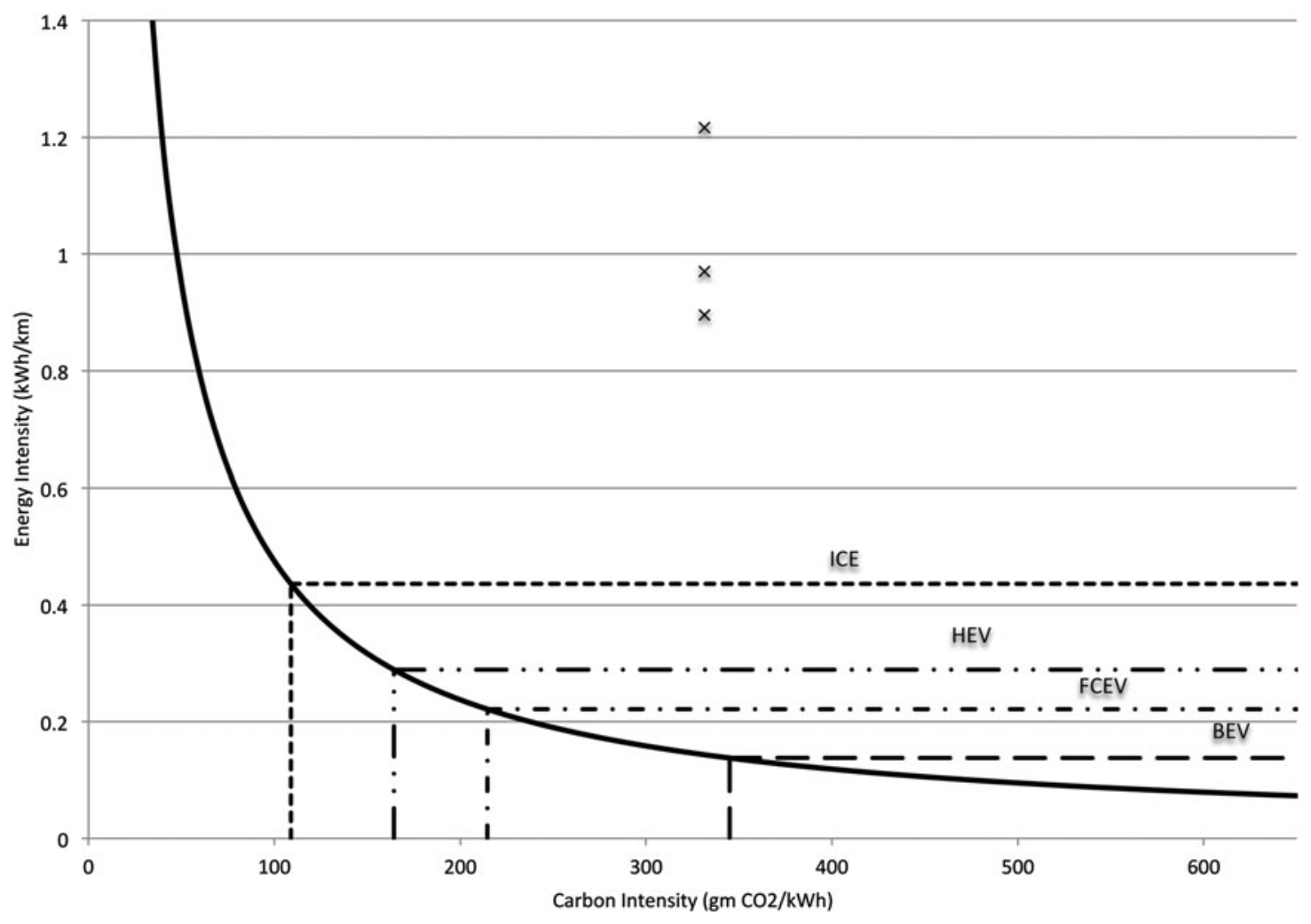

Figure 1. Solid line represents a $2015 \mathrm{GHG}$ emissions target. The upper and lower points labeled with $x$ 's represent the 2009 light-duty truck and light-duty car average GHG emissions, respectively. The middle point labeled with an $x$ is the kilometers-driven average of these two points. The four horizontal lines labeled ICE, HEV [hybrid electric vehicle], FCEV [fuel cell electric vehicle], and BEV are the estimated 2035 potential for average El by powertrain type. The corresponding vertical lines represent the corresponding $\mathrm{Cl}$ targets required to $2050 \mathrm{GHG}$ emissions targets.

vehicles. Light-duty sales in the United States fluctuate with the economy, but are typically in the range of 16 million vehicles per year, ${ }^{21}$ so the time scale required to replace the U.S. fleet of light-duty vehicles is about 15 years. Therefore, to meet a 2050 fleet average target, industry needs solutions that can begin to be sold in high volumes by 2035 . For this reason, 2035 technology projections for EI and 2050 CI projects are compared against 2050 GHG targets.

\section{Reduce the energy intensity of the vehicle}

To put EI reduction into context, first a simplified model of energy flows in a vehicle is built. This provides a framework for various energy-reduction strategies. The simplified vehicle model is shown in Fig. 2 and is based on a model used by Sovran and Blaser. ${ }^{22}$

In this model, EI is the sum of the energy per unit distance driven that goes to the wheels $\left(E_{\mathrm{W}}\right)$, auxiliaries $\left(E_{\mathrm{A}}\right)$, and parasitic losses $\left(E_{\mathrm{P}}\right)$. In addition, there are losses due to inefficiencies in the prime mover (traditionally an engine, but it could also be a fuel cell system or a battery) and the drivetrain. The efficiencies of these are given by $\eta_{P M}$ and $\eta_{D T}$, respectively. For an ICE, the prime-mover efficiency is usually referred to as the indicated efficiency of the engine.
This is a purely algebraic model, defined by Eqs. (2)-(4).

$$
\begin{gathered}
\mathrm{EI}=\frac{E_{\mathrm{DR}}+E_{\mathrm{A}}+E_{\mathrm{P}}}{\eta_{\mathrm{PM}}}, \\
E_{\mathrm{DR}}=\frac{E_{\mathrm{W}}}{\eta_{\mathrm{DT}}}, \\
E_{\mathrm{W}}=E_{\mathrm{TR}}-\xi E_{\mathrm{BR}} .
\end{gathered}
$$

The energy at the wheels is evaluated by integrating the wheel power equation with respect to time. When the wheel

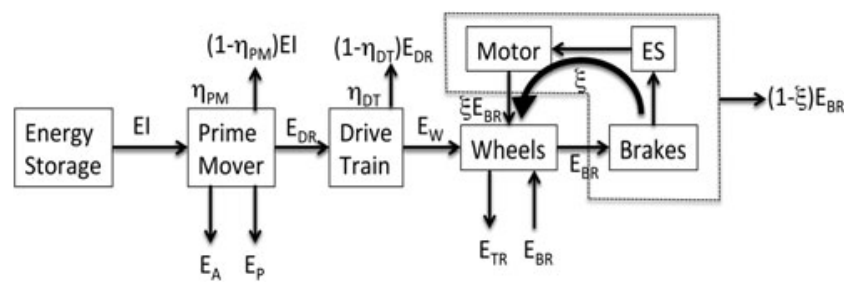

Figure 2. Simplified vehicle energy flow model used as a framework for assessing various vehicle El reduction opportunities. 
power is positive, the vehicle must provide tractive energy $\left(E_{\mathrm{TR}}\right)$. When the wheel force is negative, the vehicle must shed excess energy $\left(E_{\mathrm{BR}}\right)$. Some of this energy is lost through air or tire resistance. The rest is dissipated as heat in the brakes or powertrain. Some fraction $(\xi)$ of the otherwise lost energy can be recovered through regenerative braking if the vehicle is equipped with such a system. The energy required at the wheels depends upon the acceleration and velocity of the vehicle. The velocity and acceleration of the vehicle as a function of time are known as the drive trace. For any given drive trace, the wheel energy is a simple function of three design parameters of the vehicle and integrals of the drive trace. ${ }^{22-24}$ In this paper, the relationships from Sovran and Blaser for tractive and braking energies are used for the U.S. Environmental Protection Agency highway/city combined cycle ${ }^{25}$ shown in Eqs. (5) and (6).

$$
\begin{aligned}
& E_{\mathrm{TR}}=190.8 C_{\mathrm{d}} A+8.087 M C_{\mathrm{rr}}+0.1072 M, \\
& E_{\mathrm{BR}}=0.1072 M-21.74 C_{\mathrm{d}} A-1.723 M C_{\mathrm{rr}} .
\end{aligned}
$$

In these equations, $C_{\mathrm{d}}$ is the coefficient of aerodynamic drag, and $A$ is the frontal area of the vehicle. These two parameters always appear together and can be thought of as a single vehicle parameter, $C_{\mathrm{d}} A$. The mass of the vehicle is given by $M$, and $C_{\mathrm{rr}}$ is the coefficient of rolling resistance.

In this model, a vehicle is defined by only eight parameters. For comparison, two baseline vehicles will be used. These are not based on any specific vehicles, but are generally typical of new 2015 vehicles and consistent with losses in real vehicles. ${ }^{26}$ The parameters defining these vehicles are given in Table 1.

Before looking at specific EI reduction opportunities, it is worth looking at the theoretical limits of EI reduction. If it is assumed that vehicles have no auxiliary loads, perfect energy conversion, and perfect regenerative braking, and must drive the same drive traces used today, the theoretical minimum of EI is given by Eq. (7).

$$
\mathrm{EI}_{\text {min }}=212.5 C_{\mathrm{d}} A+9.8 M C_{\mathrm{rr}} .
$$

Assuming that these vehicles use gasoline as fuel, what set of vehicle parameters could theoretically meet 2050 GHG targets if they had perfect energy conversion and perfect energy recuperation and required no energy for auxiliaries such as climate control, lighting, and entertainment? Given the CI of gasoline, the EI required is $0.143 \mathrm{~kW} \mathrm{h/km}$. Inserting this EI into Eq. (7) and solving for the vehicle mass, the expression for the allowable mass of a theoretically perfect vehicle as a function of $C_{\mathrm{d}} A$, and $C_{\mathrm{rr}}$ is given in Eq. (8).

$$
M<\frac{515-212.5 C_{\mathrm{d}} A}{9.8 C_{\mathrm{rr}}} .
$$

Typical values of $C_{\mathrm{d}} A$ range from $0.4 \mathrm{~m}^{2}$ for very small, aerodynamic vehicles up to $1.6 \mathrm{~m}^{2}$ for large, boxy SUVs. Values of $C_{\mathrm{rr}}$ range from 0.008 to $0.017 .^{23}$ The maximum allowable mass to meet the theoretical minimum EI as a function of typical values of $C_{\mathrm{d}} A$ for three different values of $C_{\mathrm{rr}}$ is plotted in Fig. 3.
This graph illustrates a couple of notable points. First, the acceptable mass is a very strong function of $C_{\mathrm{d}} A$ and $C_{\mathrm{rr}}$. The left side of the graph represents very small profile, very aerodynamic vehicles. From this graph, it is apparent that these vehicles could be fairly massive and meet the GHG targets. In fact, the mass limits on this side of the graph are large enough that it seems quite likely that, even after adjusting for energy conversion and parasitic losses, a small, aerodynamic car that would meet 2050 GHG targets on gasoline could be designed. Moving to the right on this chart, more typical sedans appear at approximately $C_{\mathrm{d}} A=0.7 \mathrm{~m}^{2}$, smaller SUVs around $1.2 \mathrm{~m}^{2}$, and large SUVs and pickups around $1.6 \mathrm{~m}^{2}$. Moving to the right, the allowable mass becomes much smaller very quickly. For sedans, it is still theoretically possible to meet GHG limits using gasoline, but it would be very difficult. Further to the right, for larger vehicles, meeting GHG emissions using gasoline will require significant mass reduction.

This should not be interpreted to mean that vehicle efficiency improvement measures are not important. In fact, these are among the most cost-effective means of reducing GHG emissions. The relative impact of mass reduction, aerodynamic improvement, and rolling resistance reduction depends upon the drive cycle.

There are several types of design changes that can reduce the EI of a vehicle. Potential reductions in vehicle EI in two broad classes of reduction independent of the type of powertrain, which will apply to all vehicle types, and EI reductions specific to powertrain types are examined. The powertrain-specific opportunities are segregated into four powertrain types: ICE, hybrid electric (HEV), fuel cell electric (FCEV), and BEV. To illustrate the effects of potential vehicle actions, a simple energy flow model is built, and the potential to improve EI between now and 2035 is examined. Estimates of the magnitude of these potential vehicle improvements are taken from a wide range of sources. These values are not predictions, but should be taken as estimates of what is possible. In most cases, values for vehicle EI improvements are selected consistent with mid-term estimates of the 2013 National Research Council report. ${ }^{4}$

\section{Mass reduction}

Historically automobiles have been made of about $75 \%$ low-carbon steel. This percentage was pretty consistent from the early 1900s through the mid 1970s. In the period from 1977 through 2007 the fraction of low-carbon steel dropped from about $75 \%$ to about $62 \% .{ }^{27}$ Mass reduction is achieved by replacing heavy steel components with components made of less dense metals, plastics, or composites.

High strength steels and advanced high strength steels are steel alloys with higher yield strength than traditional steels. Although the density of high strength steel is essentially the same as conventional steel, because of its higher strength automotive components can be redesigned to achieve the same function with less steel. Due to its higher strength, forming and joining of high strength steel is more difficult than low-carbon steel. ${ }^{28}$

Aluminum alloys have about $40 \%$ the density of steel. The use of aluminum in automobiles has increased from about $5 \%$ in the 
Table 1. Baseline vehicle assumptions, vehicle parameters, and estimated Els for the four drivetrains assessed.

\begin{tabular}{|c|c|c|c|c|c|c|c|c|c|c|}
\hline & $\begin{array}{l}\text { Base } \\
\text { line } \\
\text { car }\end{array}$ & $\begin{array}{l}\text { Baseline } \\
\text { light-duty } \\
\text { truck }\end{array}$ & $\begin{array}{l}2035 \\
\text { ICE } \\
\text { car }\end{array}$ & $\begin{array}{c}2035 \text { ICE } \\
\text { light-duty } \\
\text { truck }\end{array}$ & $\begin{array}{l}2035 \\
\text { HEV } \\
\text { car }\end{array}$ & $\begin{array}{c}2035 \text { HEV } \\
\text { light-duty } \\
\text { truck }\end{array}$ & $\begin{array}{l}2035 \\
\text { FCEV } \\
\text { car }\end{array}$ & $\begin{array}{c}2035 \text { FCEV } \\
\text { light-duty } \\
\text { truck }\end{array}$ & $\begin{array}{l}2035 \\
\text { BEV } \\
\text { car }\end{array}$ & $\begin{array}{c}2035 \text { BEV } \\
\text { light-duty } \\
\text { truck }\end{array}$ \\
\hline$C_{d} A\left(\mathrm{~m}^{2}\right)$ & 0.7 & 1.2 & 0.56 & 0.96 & 0.56 & 0.96 & 0.56 & 0.96 & 0.56 & 0.96 \\
\hline$C_{r r}$ & 0.013 & 0.017 & 0.011 & 0.014 & 0.011 & 0.014 & 0.011 & 0.014 & 0.011 & 0.014 \\
\hline$M(\mathrm{~kg})$ & 1500 & 2000 & 1200 & 1600 & 1200 & 1600 & 1200 & 1600 & 1200 & 1600 \\
\hline$E_{\mathrm{A}}(\mathrm{kW} \mathrm{h} / \mathrm{km})$ & 0.025 & 0.040 & 0.020 & 0.032 & 0.020 & 0.032 & 0.020 & 0.032 & 0.020 & 0.032 \\
\hline$E_{\mathrm{P}}(\mathrm{kW} \mathrm{h} / \mathrm{km})$ & 0.044 & 0.07 & 0.018 & 0.029 & 0.009 & 0.015 & 0.000 & 0.000 & 0.000 & 0.000 \\
\hline$\eta_{P M}$ & $36 \%$ & $36 \%$ & $38.2 \%$ & $38.2 \%$ & $47.7 \%$ & $47.7 \%$ & $56 \%$ & $56 \%$ & $90 \%$ & $90 \%$ \\
\hline$\eta_{D R}$ & $80 \%$ & $80 \%$ & $87 \%$ & $87 \%$ & $87 \%$ & $87 \%$ & $90 \%$ & $90 \%$ & $90 \%$ & $90 \%$ \\
\hline$\xi$ & $0 \%$ & $0 \%$ & $0 \%$ & $0 \%$ & $60 \%$ & $60 \%$ & $60 \%$ & $60 \%$ & $60 \%$ & $60 \%$ \\
\hline El (kW h/km) & 0.628 & 0.998 & 0.384 & 0.608 & 0.252 & 0.413 & 0.192 & 0.317 & 0.120 & 0.197 \\
\hline mpgge & 33.5 & 21.1 & 54.8 & 34.6 & 83.7 & 51.0 & 109.4 & 66.4 & 175.8 & 106.7 \\
\hline VKT average EI & \multicolumn{2}{|c|}{0.714} & \multicolumn{2}{|c|}{0.436} & \multicolumn{2}{|c|}{0.289} & \multicolumn{2}{|c|}{0.221} & \multicolumn{2}{|c|}{0.138} \\
\hline
\end{tabular}

late 1980 s to over $10 \%$ in 2007 . Much of this has come with the increased use of aluminum cylinder heads and engine blocks. ${ }^{29}$ Increasingly aluminum is also being used for sheet panels. In 2014 Ford Motor Company produces a full sized pickup truck with an all aluminum body that is $15 \%$ lighter than their previous model. ${ }^{30}$

Magnesium is the lowest density metal used in automotive applications. The density of magnesium is about $30 \%$ lower than aluminum and $75 \%$ less than steel. Although it has lower modulus, strength, and hardness than aluminum it has some manufacturing advantages over aluminum. ${ }^{31}$ Currently magnesium components only make up a very small fraction of vehicle composition. ${ }^{29}$

Carbon fiber composites have more strength and low density. As such they have potential to replace structural components in vehicles. To date cost and manufacturing speed have limited these to low-volume niche vehicles.

In the near term (2020-2030), it is estimated that vehicle masses can be reduced by up to $20 \%$, resulting in a $12-16 \%$ reduction in fuel consumption and a similar reduction in GHG emissions. ${ }^{4,11,29}$ Larger mass reductions may be possible in the longer term, but these larger reductions will require significant redesign of the vehicles and may require the widespread adoption of active crash-avoidance technology. A $20 \%$ mass reduction is used here.

\section{Rolling resistance}

Reduction in rolling resistance through better tire design and materials will decrease energy consumption by $1-2 \%$ per $10 \%$ reduction in rolling resistance. This can be done without having a significant adverse effect on traction or tire wear. ${ }^{32-34}$ Projections are that rolling resistance could be reduced by about $16 \%$ by 2030 and as much as $30 \%$ by 2050.4 The more conservative value of $16 \%$ is used here.

\section{Aerodynamic drag}

As with rolling resistance, a reduction in aerodynamic drag of $10 \%$ will result in a $1-2 \%$ increase in fuel economy. Estimates of the potential for aerodynamic drag reduction potential for light-duty vehicles is $20-35 \%$ in the 2030 to 2050 time frame. ${ }^{4}$ Aerodynamic drag is a function of the vehicle frontal area and vehicle streamlining. To a large extent, these are determined by vehicle styling and size and are difficult to change without affecting consumer perception. However, there are less visible actions that can be taken to improve aerodynamics.

Airflow under a vehicle is a major source of drag. Smoothing of the underbody and adjusting ride height can reduce this source of drag. Active radiator shutters can reduce drag when cooling loads allow. Wheel well covers, elimination of 


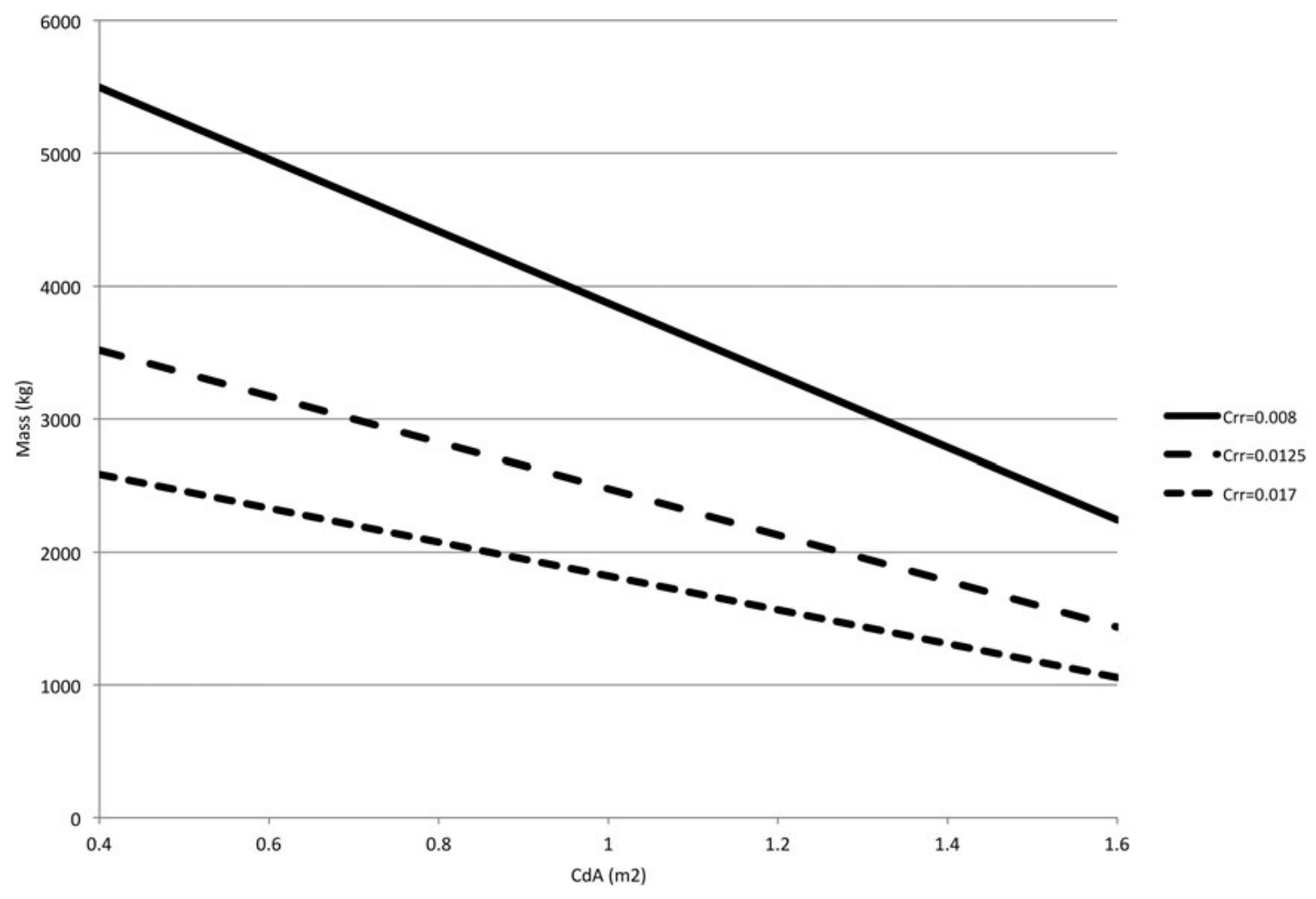

Figure 3. Theoretical maximum allowable mass for vehicle is perfect energy conversion, perfect regenerative braking, no parasitic losses, no auxiliary loads, and driving the EPA combined cycle.

side mirrors, and shape optimization all have the potential to reduce the coefficient of drag. ${ }^{35}$ A $20 \%$ reduction in drag is used here.

\section{Auxiliary loads}

Vehicle accessories also consume energy that must be accounted for in the EI of the vehicle. Although these loads are typically small compared to the energy used for propulsion in conventional vehicles, they are generally continuous loads and can have a significant impact on the EI of battery electric drivetrains. This has a significant impact on the range of these vehicles. Given limited driving range of BEVs, one of the biggest barriers to BEV adoption, reducing auxiliary loads will be very important.

Major opportunities for auxiliary load reduction include improved heating, ventilating, and air conditioning (HVAC) system control and design, reduction of thermal loads through reflective paint and low-transmissivity glass, and improving ventilation. These improvements have the potential to reduce HVAC losses by about $30 \% .{ }^{36}$ Electrification of power steering and other auxiliary components present significant additional opportunities for reducing energy loads. Historically, auxiliary components are driven by mechanical accessory drives that are much less efficient than electrical accessory drives. ${ }^{11}$ An estimate of the potential for reduction of auxiliary loads is $21-25 \%$ by $2030 .{ }^{4}$ A reduction of $21 \%$ will be used.

\section{Energy conversion efficiency}

The largest energy losses in light-duty vehicles are from the engine, which accounts for about $68 \%$ of the fuel energy losses and represents the largest potential EI improvement. There is significant opportunity to improve the combustion process and reduce losses in conventional ICEs. In addition to these improvements, hybridization provides additional opportunities to operate the engine at its highest efficiency point more of the time. The energy conversion efficiency in vehicles that use hydrogen fuel cells or batteries as the primary power source is inherently much higher than that of ICE vehicles.

\section{Internal combustion engine}

Spark-ignited gasoline ICEs are the dominant powertrain in the U.S. light-duty vehicle fleet. Steady efficiency improvements have been made in these engines. Gasoline direct injection is replacing port fuel injection in the marketplace. As of 2014 gasoline direct injection engines accounted for $42.5 \%$ of new car sales and $30.5 \%$ of light-duty truck sales in the United States. ${ }^{37}$ Gasoline direct injection engines are often coupled with turbocharging and downsizing to further improve engine efficiency. Variable valve timing and cooled exhaust gas recirculation can further increase efficiency. These technological advances have resulted in improvement in energy efficiency in recent years. ${ }^{11,12,38,39}$ 
Future powertrains can be equipped with start-stop systems that allow the engine to turn off when the vehicle is not in motion, eliminating most of the idle losses. ${ }^{40}$ These systems allow vehicles to turn the engine off during idle conditions and restart quickly when needed. These have the effect of essentially reducing idle losses to zero. In 2014, $4.6 \%$ of new vehicle sales included this technology, which will be offered as a no- or lowcost option on a large number of models in coming years. ${ }^{37}$ Because these systems are relatively inexpensive and likely to be widespread by 2035, their benefit as a potential solution for conventional ICE vehicles is included. These benefits will be captured in the model as a reduction in parasitic losses. A combination of technologies that could improve ICE combustion efficiency by about $6 \%$ and reduce parasitic losses by almost $60 \%$ by 2035 is assumed.

Transmissions will continue to improve between now and 2035. Six-speed transmissions are already common. There is a potential to replace these with eight- and nine-speed transmissions. This allows the engine to run close to its maximum efficiency point more of the time. Improved lubrication and design will also reduce friction losses in the transmission. Overall drive train efficiency could improve by about $9 \%$ between now and 2035. ${ }^{4}$

\section{Hybrid electric vehicles}

The efficiency of ICE powertrains can be further increased through hybridization. HEVs combine an ICE with an electric motor and an energy storage system. All of the energy still comes from fuel stored on the vehicle, but the EI of the powertrain is reduced through a number of mechanisms. In addition to the benefits of start-stop systems and electrified auxiliary components, hybrid systems allow the engine to spend more of its operating time at its highest efficiency point. This increases the efficiency of the engine and reduces parasitic losses. Because the electric motor can provide power to meet peak demand, it is also possible to downsize the engine. This further reduces friction and pumping losses. Finally, hybridization allows a significant fraction of energy normally lost in during braking to be captured.

There is uncertainty in the literature as to the benefit of hybridization over nonhybridized ICEs. A paper by Saxena et al. shows engine efficiency improvements ranging from $16 \%$ to $30 \%$ depending upon the cycle. ${ }^{41}$ Ahman predicts future HEV engine efficiency to be $38 \%$ better than that of an ICE. ${ }^{42}$ Cuddy and Wipke show improvement in efficiency ranges from $40 \%$ to $55 \%$ percent for current technology. ${ }^{43}$ The 2013 National Research Council study used a model by Ricardo that estimated an $18-33 \%$ improvement between ICEs and HEVs in 2025.4

The literature reports variable estimates on this improvement potential. A $25 \%$ reduction in prime-mover efficiency and about a $50 \%$ reduction in parasitic losses will be used.

Previously, the theoretical case of perfect recuperation was studied; next, the more realistic estimate of regenerative energy recovery potential is examined. First, the tractive EI and braking EI of a vehicle driving the U.S. highway and urban combined cycles can be estimated. From these, the ratio of braking energy to tractive energy required for a vehicle can be estimated. This ratio depends upon the vehicle's rolling resistance, mass, and $C_{\mathrm{d}} A$. It ranges from about $22 \%$ for small, aerodynamic vehicles with low rolling-resistance tires to about $43 \%$ for larger, less aerodynamic vehicles. ${ }^{22}$ This represents the fraction of tractive energy that could be offset by regenerative breaking. Realistically, regenerative braking systems have a round-trip efficiency of only about $60 \% .^{23}$ Therefore, a realistic estimate of the fraction of tractive energy that can be offset is in the range of $13-26 \%$.

In sum, ICE light-duty vehicles have the potential to reach an average EI of about $0.436 \mathrm{~kW} \mathrm{~h} / \mathrm{km}(47.5 \mathrm{mpg}$ ) without hybridization and $0.289 \mathrm{~kW} \mathrm{~h} / \mathrm{km}(71.7 \mathrm{mpg})$ with hybridization by 2035. These values are shown as the lines marked "ICE" and "HEV" in Fig. 1. These values are low, but not low enough to meet 2050 GHG emissions targets if these vehicles are operated on gasoline.

\section{Fuel cell electric vehicles}

Fuel cell vehicles are electric vehicles that generate their electricity from hydrogen stored on board the vehicle using a fuel cell. A fuel cell is an electrochemical device that converts fuel directly to electricity. In automotive applications, these are proton exchange membrane (PEM) fuel cells. In a PEM fuel cell, hydrogen fuel flows past an electrode on one side of the PEM, and air moves past an electrode on the other side of the membrane. Catalysts in each electrode split the hydrogen molecules into protons and electrons and the oxygen molecules into individual atoms. The PEM allows the protons from the hydrogen side to pass through the membrane to the oxygen side, but does not allow the electrons to pass. On the oxygen side of the membrane, each oxygen atom combines with two protons and two electrons to form water. Because the electrons cannot pass through the membrane, they move through a circuit from the hydrogen electrode to the oxygen electrode, generating electricity.

Compared to ICEs, fuel cells are very efficient. Vehicles in the DOE's hydrogen fuel cell learning demonstration had typical fuel cell systems efficiencies of about $56 \% .{ }^{44}$ In addition to high efficiency, they have the advantage of no tailpipe emissions other than water, a relatively large driving range between refills, and fast refill times. ${ }^{45}$

First-generation fuel cells were expensive and did not have the lifetimes expected of commercial automotive powertrain components. Both affordability and lifespan have improved considerably in the later-generation fuel cells, but these factors are still barriers to market adoption. Although it is possible to make further increases in system efficiency between now and 2035 , it is likely that most improvement efforts will focus on cost reduction and increased life.

A system efficiency of $56 \%$ will be used as the prime-mover efficiency. This is the fuel cell system-level efficiency, so it already takes into account parasitic losses due to moving parts in the system. For this reason, 0 is used for parasite losses in the simplified model.

FCEV powertrains combine a fuel cell with a high-voltage battery to recover regenerative braking energy and help smooth out power demands. Because of this, the same $60 \%$ regeneration 
round-trip efficiency factor is used as was used for HEVs. Power is delivered to the wheels by an electric motor. The efficiency of an electric motor system peaks at $95-96 \%$ and goes down to lows in the mid-80\%. ${ }^{4,24,46,47} \mathrm{~A}$ value of $90 \%$ is used as a reasonable average value, which provides an EI estimate of $0.221 \mathrm{~kW} \mathrm{~h} / \mathrm{km}$ [93.6 miles per gallon gasoline equivalent (mpgge)]. This value is shown by the line marked "FCEV" in Fig. 1.

\section{Battery electric vehicles}

$\mathrm{BEV}$ s have the highest prime-mover efficiency. In the case of $\mathrm{BEVs}$, the prime mover efficiency is the round-trip chargedischarge efficiency of the battery. Compared to other primemover efficiencies, this is very high. The target round-trip efficiency for automotive batteries is $90 \%$ or greater. ${ }^{48}$ This value will be used for prime-mover efficiency, which provides an estimated EI of $0.138 \mathrm{~kW} \mathrm{~h} / \mathrm{km}$ (150.4 mpgge). This is shown as the line marked "BEV" on Fig. 1.

The principal shortcomings of BEVs are the low energy density of the batteries and the long recharge times. Because of this, the distance they can drive on a single battery charge is considerably less than that possible on a typical tank of gasoline. Thus, even with a large penetration of electric vehicles, it will be difficult to electrify all of the VKT. Most vehicle trips are short enough that electric vehicles have sufficient range to make these trips, even with current battery energy densities. Although short trips account for most of the trips taken, long trips account for a disproportionate fraction of the kilometers traveled, and the range of BEVs is not sufficient for these trips.

For most drivers, there will be a number of trips that the BEV cannot make on a single charge. Presumably, these additional trips will still be taken, just not in an electric vehicle. This sets up a tension in electric vehicle drivers. If batteries are small, they are cheap, but will electrify fewer of the driver's trip needs. As batteries get bigger, they will electrify more of the driver's trips, but at a higher marginal cost. These two competing effects likely will limit the total kilometers driven that can be electrified. This effect is mitigated somewhat with plug-in HEVs. With these vehicles, the range limitations will not be a problem, but there will still be a limit to the number of miles that are electrified. ${ }^{49}$

The assumed vehicle parameters and estimated EIs for the four drivetrains assessed, as well as the baseline vehicle assumptions, are given in Table 1. Figure 4 shows the breakdown of EI for these vehicles. In this figure, the engine losses include losses due to prime-mover inefficiency and parasitic losses. Energy at the wheels is the traction energy required minus energy recovered from regenerative breaking. Driveline losses are losses due either to transmission or electric motor inefficiencies.

\section{Decrease the carbon intensity of the energy source}

The second kind of action can include actions that reduce the CI of the energy sources used for transportation. For each of the potential EIs shown in Fig. 1, the point where they cross the $2050 \mathrm{GHG}$ target can be calculated to get an upper limit on the acceptable CI for each power source. These are compared to the CIs of energy sources currently used to look at the potential for those energy sources to reduce CI enough to hit $2050 \mathrm{GHG}$ targets. CIs of various energy sources for transportation are reviewed in a number of Refs. $4,17,50,51$. Three possible energy carriers will work on board vehicles: electricity, hydrogen, and carbon-based fuels. Each of these energy carriers can be produced from multiple energy sources.

\section{Biofuels}

First, energy sources for ICEs and HEVs are examined. Currently, these vehicles are fueled with gasoline that has a CI of $332 \mathrm{~g} \mathrm{CO}_{2} / \mathrm{kW} \mathrm{h} .^{4}$ Projections for $2035 \mathrm{EI}$ for ICE lightduty vehicles are $0.436 \mathrm{~kW} \mathrm{~h} / \mathrm{km}$ without hybridization and $0.289 \mathrm{~kW}$ h/ $\mathrm{km}$ with hybridization. Based on these numbers, the United States will require between 55 and 83 billion gge a year. The United States consumption in 2014 was 137 billion gallons of gasoline. ${ }^{52}$

Although this is a significant reduction, it is not enough to meet an $80 \%$ reduction in GHG emissions. To meet $2050 \mathrm{GHG}$ targets, the CI of the fuel will have to be less than $109 \mathrm{~g} \mathrm{CO}_{2} / \mathrm{kW} \mathrm{h}$ for ICEs and $164 \mathrm{~g} \mathrm{CO}_{2} / \mathrm{kW} \mathrm{h}$ for HEVs. Presumably this reduction in CI will be met through the use of biofuels.

If it is assumed that some significant fraction of the transportation energy continues to be provided by gasoline, it is useful to know the fraction of the energy that will have to be displaced by biofuels to meet this goal. Clearly this depends upon the CI of the biofuel.

It should be noted that it is difficult to assess the CI of biofuels. With biofuels, it is assumed that some fraction of the tail-pipe carbon emissions and upstream process emissions are offset by absorption of $\mathrm{CO}_{2}$ by the feedstock used to produce the fuel. This requires careful accounting. The widely accepted methodology for this is life-cycle analysis, which is embodied in the GREET model. ${ }^{53}$ However, there have been some questions posed in the literature as to whether or not this analysis correctly accounts for the carbon fixing. ${ }^{54}$

For a given $\mathrm{CI}$ of biofuels $\left(\mathrm{CI}_{\mathrm{b}}\right)$, the fraction of biofuel $\left(f_{\mathrm{b}}\right)$ needed to meet a $\mathrm{CI}$ target $\left(\mathrm{CI}_{\mathrm{T}}\right)$ is given by:

$$
f_{\mathrm{b}}=\frac{\mathrm{CI}_{\mathrm{g}}-\mathrm{CI}_{\mathrm{T}}}{\mathrm{CI}_{\mathrm{g}}-\mathrm{CI}_{\mathrm{b}}},
$$

where $\mathrm{CI}_{\mathrm{g}}$ is the $\mathrm{CI}$ of gasoline.

This is plotted for a CI target for ICEs and HEV s in Fig. 5. The red line represents the fraction for ICEs, and the black line the fraction for HEVs. From this figure, it can be seen that even with a fleet of very efficient HEVs, more than half of the energy will have to come from low-carbon biofuels to meet GHG targets.

There is a lot of variation in the estimates of the CI of biofuel in the literature. Sources of this variation include differences in feedstock, production methods, and land use changes. For example, estimates of land-use-change contributions to CI range from 18 to $378 \mathrm{~g} / \mathrm{kW}$ h for corn ethanol. ${ }^{55}$ Variation in GHG emissions of corn ethanol production due to the type of processing plant ranges from $3 \%$ greater than gasoline to $52 \%$ less than gasoline on a per-unit energy basis. ${ }^{56}$ 


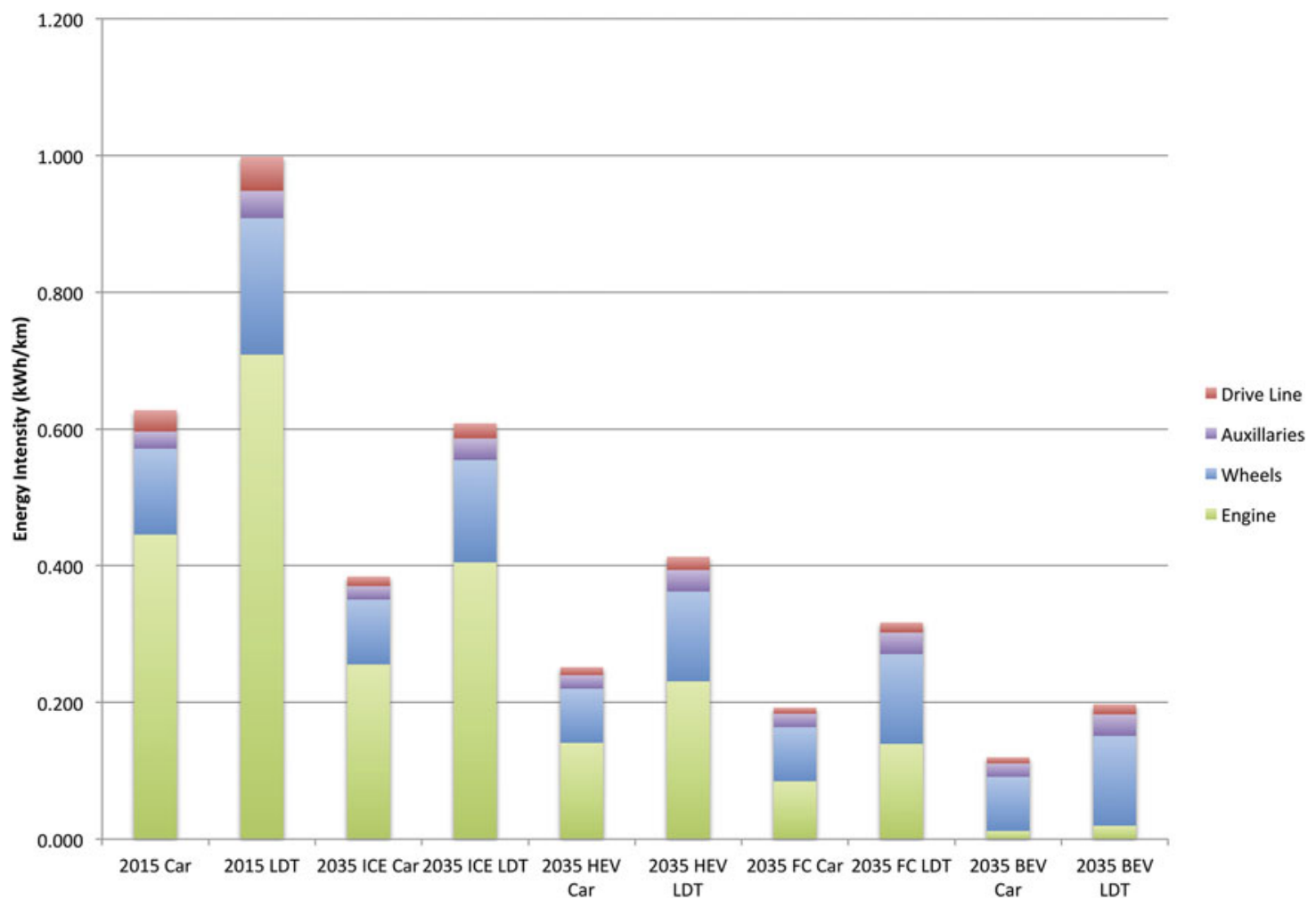

Figure 4. Distribution of El for the four drivetrains considered. Engine losses include losses due to prime-mover inefficiency and parasitic losses. Energy at the wheels is the traction energy required minus energy recovered from regenerative breaking. Driveline losses are losses due either to transmission or electric motor inefficiencies.

The National Research Council Transitions to Alternative Vehicles and Fuels study estimates CIs for biofuel from 95 to $148 \mathrm{~g} \mathrm{CO}_{2} / \mathrm{kW} \mathrm{h.}{ }^{4}$ The Nguyen et al. WTW study used numbers consistent with $234 \mathrm{~g} / \mathrm{kW}$ h for corn-grain ethanol and $54 \mathrm{~g} / \mathrm{kW}$ h for cellulosic ethanol. ${ }^{17}$ Using the value from Nguyen et al. for cellulosic ethanol, $60-80 \%$ of the fuel energy would have to come from cellulosic ethanol depending upon the degree of hybridization in the fleet. This comes to between 33 and 66 billion gge of cellulosic ethanol. Theoretical ethanol production yields per dry ton of feedstock are $113 \mathrm{gal} / \mathrm{dry}$ ton for corn stover and $96.7 \mathrm{gal} /$ dry ton of switchgrass. ${ }^{57}$ With these yields, the United States would need 0.41 to 0.96 billion tons of corn stover or 0.471 to 1.11 billion tons of switchgrass. In reality, there would be some combination of multiple feedstocks. Based on estimates of potential feedstock production capabilities, these yields look possible in the 2050 time frame. ${ }^{58-60}$

\section{Hydrogen}

It is extremely unlikely that FCEVs will replace all light-duty vehicles by 2050 . Nevertheless, it is instructive to ask how much hydrogen would be required if they did. Assuming an average EI of $0.221 \mathrm{~kW} \mathrm{~h} / \mathrm{km}$, the United States would require 42 billion $\mathrm{kg}$ of hydrogen fuel. An industry-based report from General Motors Corporation states that globally 40 billion $\mathrm{kg}$ of hydrogen are produced each year. ${ }^{61}$ Although this is not sufficient to meet all the light-duty transportation energy requirements, it does indicate that there is already a significant market for the production of hydrogen. Because of this, there should be sufficient infrastructure to produce enough hydrogen for transportation purposes during early market deployment of fuel cell vehicles. Furthermore, the processes and costs associated with this production are well known. The more significant infrastructure problems are at the retail fueling level.

The CI of this hydrogen would have to be less than $214 \mathrm{~g}$ $\mathrm{CO}_{2} / \mathrm{kW}$ h. Today, virtually all hydrogen is produced by steam reformation of natural gas. The CI of hydrogen from this production pathway is $362 \mathrm{~g} \mathrm{CO}_{2} / \mathrm{kW} \mathrm{h} .{ }^{4}$ As with gasoline for ICEs, it should be assumed that much of the hydrogen would continue to be produced by this pathway. The fraction of renewable hydrogen that must be mixed in with hydrogen from natural gas to meet 2015 targets is then calculated (Fig. 6). The National Research Council report Transitions to Alternative Vehicles and Fuels estimated the CI of low-GHG hydrogen to be $77 \mathrm{~g} \mathrm{CO}_{2} / \mathrm{kW} \mathrm{h}$. Nguyen, Ward, and Johnson's WTW study estimates the CI of hydrogen produced by wind at $85 \mathrm{~g} \mathrm{CO}_{2} / \mathrm{kW}$ h. Assuming $77 \mathrm{~g}$ $\mathrm{CO}_{2} / \mathrm{kW} \mathrm{h}$ for low-GHG hydrogen pathways, $53 \%$ of transportation hydrogen would have to be generated by low-GHG pathways.

An assessment of the hydrogen production-potential indicates that there are ample low-carbon domestic resources available to supply future FCEV markets. ${ }^{62}$ 


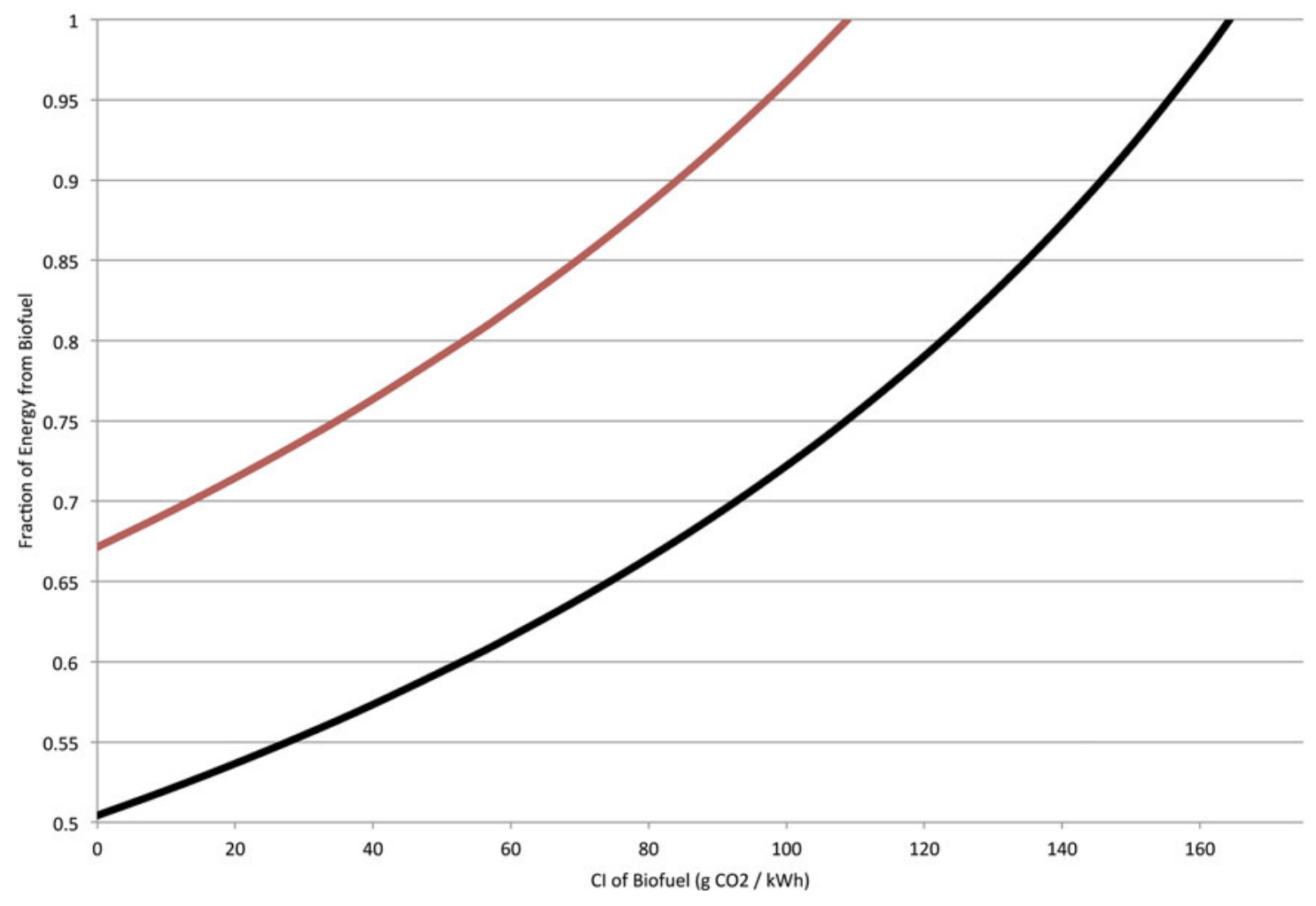

Figure 5. Fraction of energy that must come from low-carbon biofuels. The red line is the fraction for ICEs, and the black line is for HEVs.

\section{Electricity}

Based on this assessment of the EI potential for BEVs, the CI of electricity used for transportation purposes needs to be less than $345 \mathrm{~g} / \mathrm{kW} \mathrm{h}$. The amount of electrical energy required to meet U.S. light-duty transportation needs in 2050 would be about 878 billion $\mathrm{kW}$ h. Compared to 2014 U.S. electrical generation of 4113 billion $\mathrm{kWh},{ }^{63}$ this is substantial, but not impossible to meet.

Despite the relatively high CI value allowed by electrified transportation, only a few places in the United States have electricity that falls below this value. ${ }^{64}$ In 2012, the CI of electric generation in the United States ranged from less than $100 \mathrm{~g} / \mathrm{kW}$ h in parts of the Pacific Northwest to well over $900 \mathrm{~g} / \mathrm{kW} \mathrm{h}$ in parts of the country that generate a large fraction of their electricity from coal.

For the most part, U.S. electricity is generated from one of three sources: coal, natural gas, and renewables/nuclear. Estimates of the CIs of these primary sources are $1000 \mathrm{~g} / \mathrm{kW} \mathrm{h}$ for coal, $470 \mathrm{~g} / \mathrm{kW} \mathrm{h}$ for natural gas, and an average $14 \mathrm{~g} / \mathrm{kW} \mathrm{h}$ for various renewable sources and nuclear sources. ${ }^{51}$ Given these estimates, a simple three-element mixture model says that to meet the $345 \mathrm{~g} / \mathrm{kW} \mathrm{h}$ requirement, the fraction of electricity generated by renewables or nuclear must meet the following requirement:

$$
f_{\mathrm{R}}>0.66-0.54 f_{\mathrm{NG}},
$$

where $f_{\mathrm{R}}$ is the fraction of electricity from renewable or nuclear, $f_{\mathrm{NG}}$ is the fraction of electrify from natural gas, and the fraction of electric from coal is $f_{\mathrm{c}}=1-f_{\mathrm{R}}-f_{\mathrm{NG}}$. This limit is shown on the solid line on the ternary mixture plot in Fig. 7. On this plot, electrical generation above and to the right of the solid line meets the estimated $2050 \mathrm{CI}$ requirements. The solid squares are the current generation mixes for all 50 states and the District of Columbia. For comparison, the 2014 U.S. electricity grid mix was $38.5 \%$ coal, $27.3 \%$ natural gas, $32.9 \%$ renewable and nuclear, and $1.4 \%$ other. ${ }^{63}$

Although most states do not currently meet the 2050 requirement, there are vehicle technologies existing today that meet GHG emissions targets in at least some parts of the country; however, there are three problems. First, can the electric grid shift to a sufficient mix of renewable energy by 2050 ? Second, will the market accept the transition to electric vehicle between now and 2050? This is unlikely as there are many barriers to deployment of electric vehicles. ${ }^{65}$ Third, as discussed in some detail above-even if there are many BEVs, can sufficient miles be electrified by these BEVs?

\section{More-efficient transportation systems}

So far, only vehicle improvements that result in a reduced EI and about alternative energy carriers that enable reduced CI have been discussed. These approaches look at either the vehicle or the energy system in isolation. Historically, this has been a fine approach for light-duty transportation. Until recently, light-duty transportation has consisted vehicles that operate independently with little or no interaction between vehicles and interaction with the energy supply system only during fueling; 


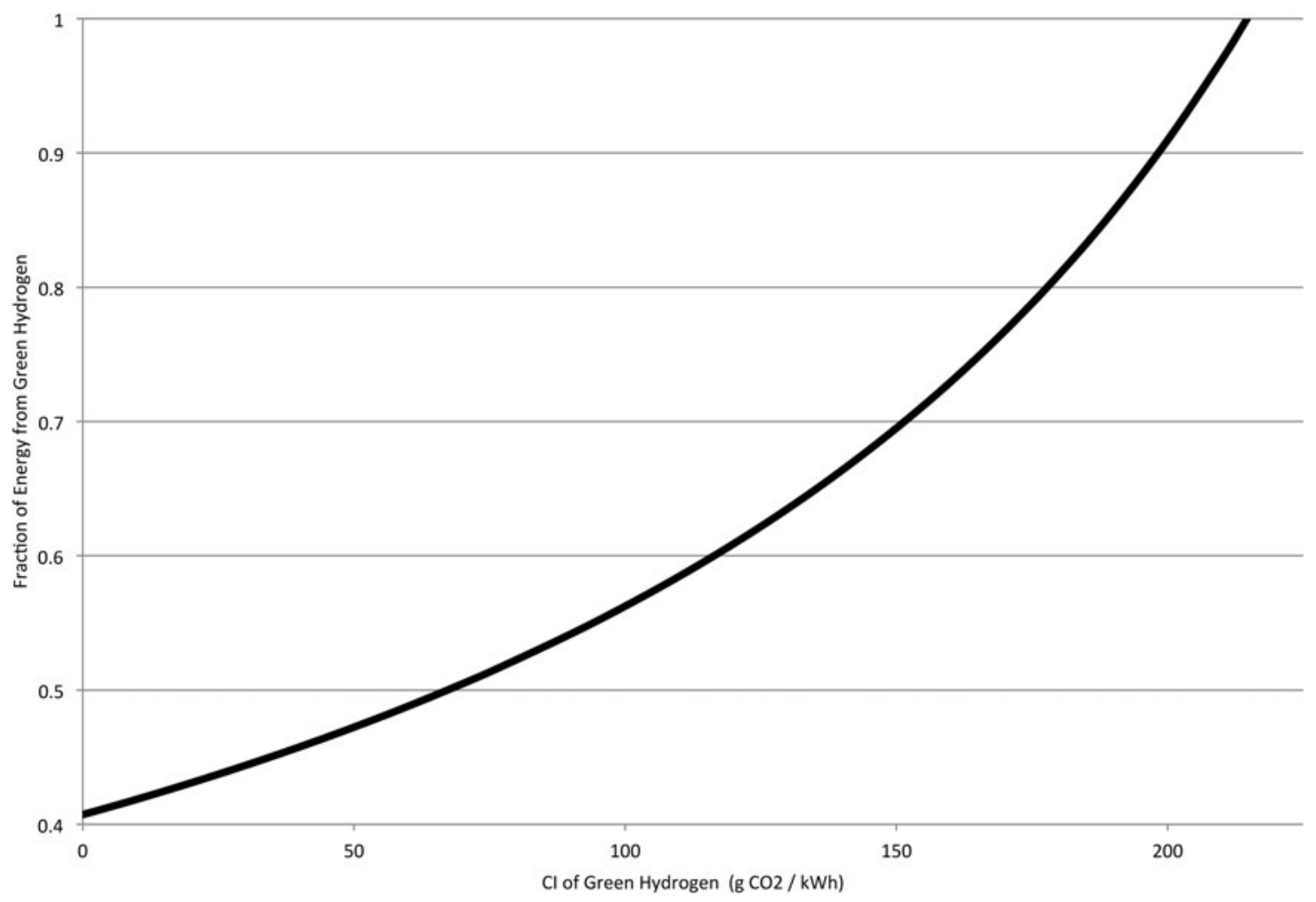

Figure 6. Fraction of transportation hydrogen that must come from low-carbon sources.

however, vehicles and travelers are becoming increasingly connected. This convergence of information technology, vehicle technology, and distributed generation of renewable energy could dramatically change how the light-duty transportation system works. ${ }^{66}$

There is a great deal of uncertainty about how information technology will impact trends in mobility. This uncertainty is reflected in the wide range of energy impact estimates. Initial studies by researchers at the NREL and Oak Ridge National Laboratory attempt to bookend the possible energy effects of connected and autonomous vehicles. These studies find that the energy effects could be anywhere from a $90 \%$ fuel savings to $150 \%$ increase in fuel use. ${ }^{67,68} \mathrm{~A}$ Rand report for policy-makers about the impacts of autonomous vehicles estimates fuel economy would improve by $4-10 \%$, but this will be offset by an increase the number of drivers, which will increase VKT. While the overall benefit is uncertain, the author believes autonomous vehicles will result in a net reduction in energy use and emissions this result is uncertain. ${ }^{69}$ An Organisation for Economic Co-operation and Development study assessment is that the likely impacts on mid-sized European cities are that the same mobility could be achieved with $10 \%$ of the vehicles and a $6 \%$ increase in VKT. ${ }^{70}$ A California Air Resources Board report states "...climate impacts of AVs [autonomous vehicles] are, at this point, ambiguous."71 Driver feedback can improve driving efficiency by $5-30 \% .{ }^{72}$ Autonomous taxis could reduce GHG emissions. ${ }^{73}$ "Green routing" has the potential to save $3-5 \%$ with no changes to the vehicles, assuming drivers can be incentivized to take the lower-energy route. ${ }^{74}$

Because of the large uncertainty, the impacts will not be estimated in this paper. Instead, the impacts connectivity could have on each of three aspects of GHG emissions will be considered: vehicle EI, CI of the transportation energy source, and VKT.

To discuss the impact of connectivity on the EI of vehicles, it is important first to distinguish between connectivity and automation. These two topics are often conflated in the literature, but they are very different. Connectivity is the sharing of information among vehicles, travelers, and the infrastructure that supports them. Automation is the ability of vehicles to perform one or more functions without input from a driver. Vehicles and travelers are already highly connected, and this trend will continue. Vehicles with high levels of automation will most likely be highly connected, if for no other reason than virtually all cars in the future will be, but connected vehicles need not be autonomous.

Reduction of vehicle EI through connectivity or automation can only take the same forms already discussed: either by reducing the energy required at the wheels or reducing losses within the vehicles. Connected vehicles that have information about the various routes, traffic conditions, signal timing, and other factors impacting energy use can select the route that minimizes energy required at the wheels. If the vehicle is also an HEV or plug-in $\mathrm{HEV}$, the vehicle may also be able to match the 


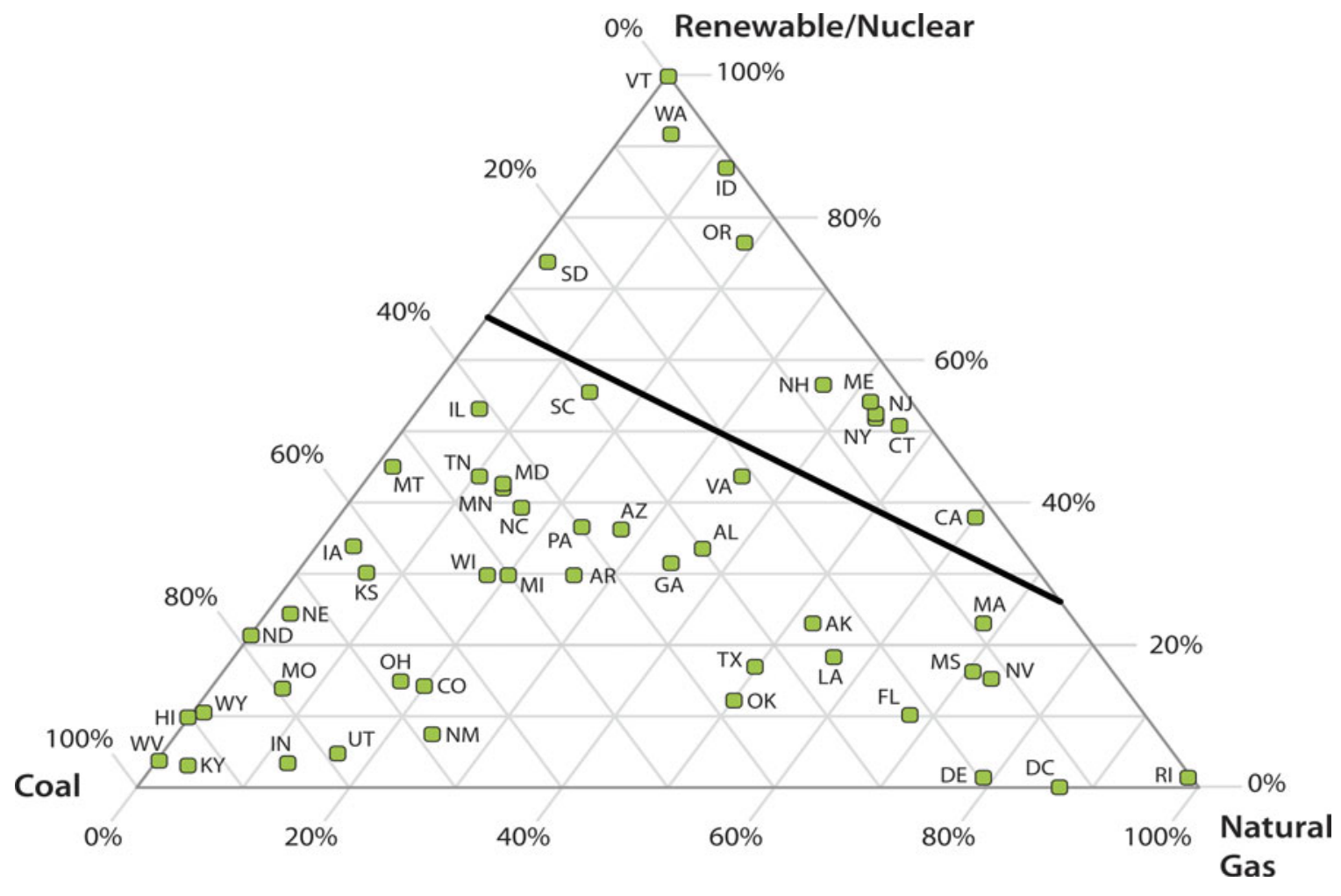

Figure 7. Ternary mixture plot of electricity generation. The top of the triangle represents $100 \%$ renewable and nuclear. The right vertex is $100 \%$ natural gas. The left vertex is $100 \%$ coal. The green squares represent the 2012 mix of electrical generation for all 50 states plus the District of Columbia. The solid line is the limit from Eq. (10). Generation mixes that meet $2050 \mathrm{GHG}$ requirements are above and to the right of the solid line.

hybridization strategy to maximize the efficiency of the powertrain over that route. This is known as "green routing." 74 Vehicles that are connected and autonomous can move in concert with each other, creating smoother traffic flow and reducing the amount of acceleration and deceleration during driving. Similarly, interactions among vehicles, traffic signals, and other infrastructure will optimize traffic flow in urban areas. This reduces the energy required at the wheels for the same distance traveled.

There are a variety of ways that connected vehicles may reduce CI. Connectivity may enable the use of alternative energy for transportation. Connected vehicles will know the location of the nearest compatible charging or fueling station. This potentially reduces some of the barriers to market penetration of these vehicles. Assuming these alternative energy sources have lower CIs than gasoline enables the reduction of CI. Connected BEVs and plug-in HEVs can interact more directly with the electric grid. This may enable a deeper penetration of renewable electricity on the grid. Autonomous vehicles could self-drive to charging and fueling stations, returning fully charged when the driver needs them. This could increase the effectiveness of the charging and fueling infrastructure, delivering the same benefits with fewer stations.

Perhaps the greatest uncertainty associated with connected and autonomous vehicles is the impact these technologies will have on VKT. These technologies may make mobility more effective so that the same societal benefit can be achieved with fewer VKT. For example, connectivity enables ride- and carsharing business models with the potential to increase vehicle occupancy and mobility efficiency. It is also possible that these same technologies will remove barriers to transportation access that will increase the total number of kilometers driven. Presumably this would increase the mobility benefit to society, but it would also increase transportation energy use and GHG emissions. Finally, with a fully autonomous vehicle, one can envision scenarios in which self-driving cars significantly reduce the cost of time lost while driving. This could promote greater urban sprawl and significant increases in VKT. These technologies also extend transportation opportunities to people who cannot drive today. This will also increase VKT. Within the context of this paper, technologies that increase VKT have the impact of reducing the allowable GHG emissions per unit distance driven.

\section{Conclusions}

This paper considers the goal of $\mathbf{8 0 \%}$ reduction in GHG emissions from light-duty transportation in the United States by 2050. Using baseline GHG emissions from 2005 and assuming VKT follows Energy Information Agency projections out to 2040 , then increases linearly from there until 2050, light-duty transportation in the United States will have to have WTW GHG emissions averaging less than $48 \mathrm{~g} / \mathrm{km}$. 
Figure 8 shows a summary of the vehicle EI improvement potential estimates from Fig. 4 superimposed onto the 2050 GHG emission target curve of Fig. 1. In this figure the 4 bars are VKT weighted averages of the car and light-duty truck results. Estimates indicate that the potential improvement in ICE-based vehicles, even with hybridization, will not be sufficient to meet these targets if these vehicles use gasoline as their energy source. To meet target GHG emission levels with ICEs, a significant fraction of the energy will have to be in the form of low net GHG biofuels. The percentage of biofuels required will depend upon the CI of the biofuels. Based on estimates of the CI for cellulosic ethanol, this percentage will be on the order of $53 \%$. To meet the energy requirements for light-duty transportation in the United States, this will require between 33 and 78 billion gge of ethanol, depending upon the degree of hybridization in the U.S. fleet. Although this is a significant amount of biofuel, studies indicate that it is attainable.

Hydrogen fuel cell vehicles using hydrogen produced with natural gas also will not be able to meet this GHG target. To meet this target, $48 \%$ of the hydrogen used for transportation fuel would have to be produced from low-carbon renewable sources such as solar or wind.
BEVs already have very low EIs. In parts of the country that already generate a significant fraction of their energy from renewable or nuclear energy, these vehicles may already meet the 2050 GHG emissions targets. To meet the GHG requirement for light-duty transportation, the grid energy used can have no more than $30 \%$ generation from coal. Even with no coal in the generation mix, the percentage of generation from renewables or nuclear must be greater than $36 \%$.

Finally, connected and autonomous vehicle technologies may create some opportunities to decrease EI or CI, but their greatest potential impact will be changed in VKT. These changes in VKT could dramatically change the target value for GHG emissions. These dramatic changes in VKT generally require a significant number of autonomous vehicles. It remains to be seen how quickly these vehicles will enter the market. It should be pointed out that this does not change the basic conclusions of this paper. Even with current projections for VKT, the EI reduction potential is not sufficient to meet 2050 GHG targets. If VKT increases significantly over these projections, this continues to be true, and it will be even more important to find ways to use low-carbon energy sources for transportation.

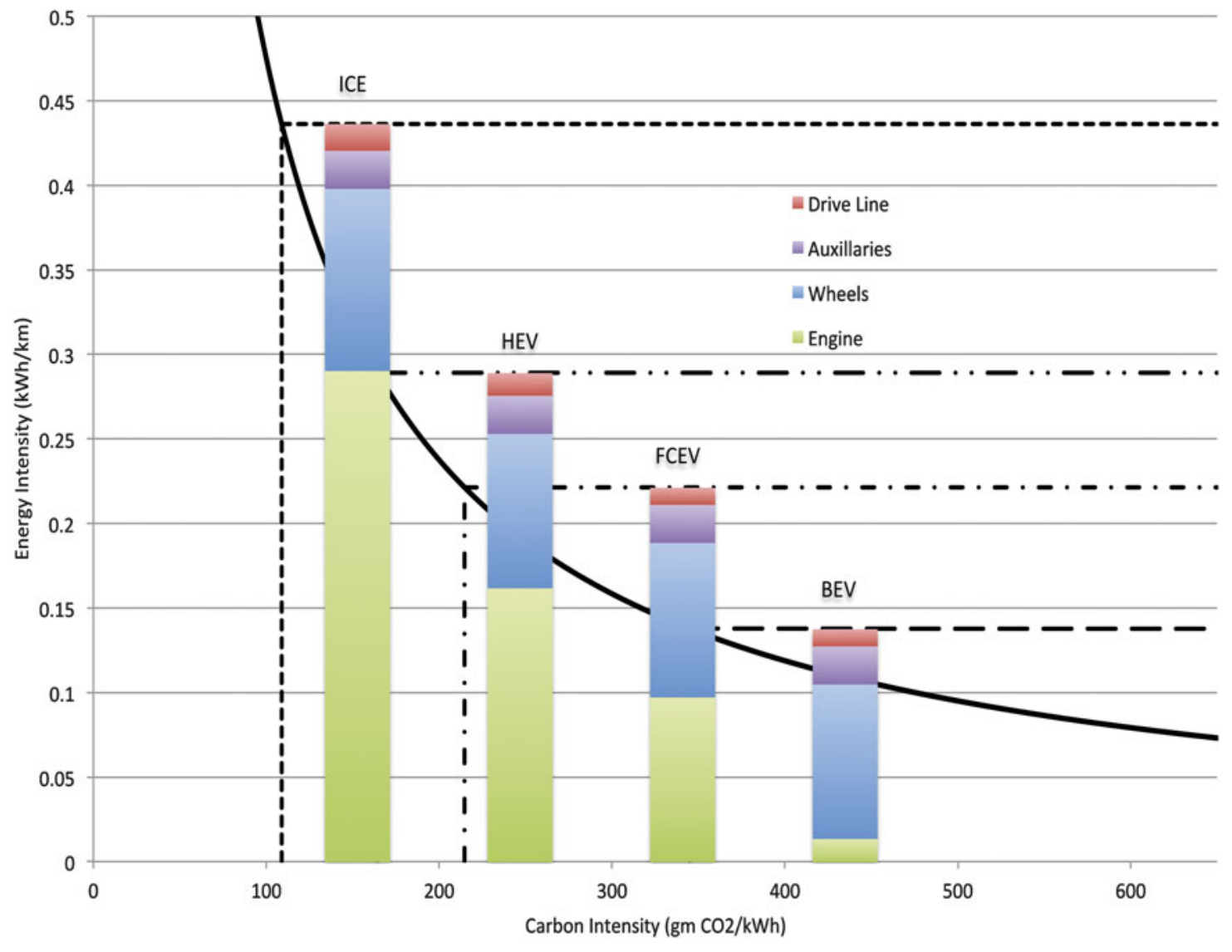

Figure 8. A superposition of the GHG emissions targets from Fig. 1 with weighted averages of the estimates of powertrain El potential from Fig. 4. Each of the stacked bars in this figure are a VKT weighted average of the car and LDT bars for each of the four 2035 powertrains considered. The weighting factors used are $76.8 \%$ cars and $23.2 \%$ LDT. 


\section{Acknowledgments}

This work was supported by the U.S. Department of Energy under Contract No. DE-AC36-08GO28308 with the National Renewable Energy Laboratory. Funding was provided by U.S. Department of Energy Office of Energy Efficiency and Renewable Energy Vehicle Technologies Office. The U.S. Government retains and the publisher, by accepting the article for publication, acknowledges that the U.S. Government retains a nonexclusive, paid-up, irrevocable, worldwide license to publish or reproduce the published form of this work, or allow others to do so, for U.S. Government purposes.

\section{REFERENCES:}

1. World Bank: Turn down the heat. In Turn Down the Heat: Why a $4{ }^{\circ} \mathrm{C}$ Warmer World Must Be Avoided. World Bank: Washington, DC, 2012.

2. IPCC 2014: Climate change 2014: Synthesis report. Contribution of Working Groups I, II and III to the Fifth Assessment Report of the Intergovernmental Panel on Climate Change. Pachaur R.K. and Meyer L.A. eds.; IPCC: Geneva, Switzerland, 2014; p. 151.

3. U.S. Energy Information Agency: Annual Energy Review 2011 (2012). Available at: http://www.eia.gov/totalenergy/data/annual/ (accessed: June 10, 2016 ).

4. National Research Council: Transitions to Alternative Vehicles and Fuels (The National Academies Press, Washington, DC, 2013) doi: 10.17226/18264.

5. Melaina M.W., Heath G., Sandor D., Steward D., Vimmerstedt L., Warner E., and Webster K.W.: Alternative Fuel Infrastructure Expansion: Costs, Resources, Production Capacity, and Retail Availability for Low-Carbon Scenarios. Transportation Energy Futures Series (Prepared for the US. Deptartment of Energy by National Renewable Energy Laboratory, Golden, CO, 2013).

6. Luers A.L., Mastrandrea M.D., Hayhoe K., and Frumhoff P.C.: How to avoid Dangerous climate change; a target for U.S. Emissions Reductions (Union of Concerned Scientists, Cambridge, MA, 2007).

7. President Obama sets a target for Cutting U.S. Greenhouse gas emissions. Available at: http://apps1.eere.energy.gov/news/news_detail.cfm/ news_id=15650 (accessed: September 3, 2015).

8. Andress D., Das S., Joseck F., and Dean Nguyen T.: Status of advanced light-duty transportation technologies in the US. Energy Policy 41, 348-364 (2012).

9. United States Department of Energy: Energy Analysis: Transportation Energy Futures Study (2014). Available at: http://energy.gov/eere/ analysis/transportation-energy-futures-study (accessed: June 12, 2016).

10. Vimmerstedt L., Brown A., Newes E., Markel T., Schroeder A., Zhang Y., Chipman P., and Johnson S.: Transformative Reduction of Transportation Greenhouse Gas Emissions: Opportunities for Change in Technologies and Systems (National Renewable Energy Laboratory, Golden, CO, 2015) NREL/TP-5400-62943.

11. National Research Council: Assessment of Fuel Economy Technologies for Light-Duty Vehicles (The National Academies Press, Washington, DC, 2011) doi: 10.17226/12924.

12. National Research Council: Cost, Effectiveness and Deployment of Fuel Economy Technologies for Light-Duty Vehicles (The National Academies Press, Washingon, DC, 2015) doi: 10.17226/21744.

13. Sandy Thomas C.E.: Transportation options in a carbon-constrained world: Hybrids, plug-in hybrids, biofuels, fuel cell electric vehicles, and battery electric vehicles. Int. J. Hydrogen Energy 34(23), 9279-9296 (2009).

14. Vimmerstedt L., Brown A., Heath G., Mai T., Melaina M., Newes E., Ruth M., Simpkins T., Warner E., Bertram K., Plotkin S., Patel D., Stephens T., and Vyas A.: Potential reductions in emissions and petroleum Use in transportation. J. Transp. Res. Board 2375, 37-44 (2013).

15. California Energy Commission: Full Fuel Cycle Assessment: Well-to-wheels Energy Inputs, Emissions, and Water Impacts (2007) CEC-600-2007-004-F.
16. Edwards R., Larive J-F., and Beziat J-C.: Well-to-wheels Analysis of Automotive Fuels and Powertrains in the European Context (European Commission Joint Research Centre, Institute for Energy, Luxembourg, 2011) EUR 24952 EN-2011.

17. Nguyen T., Ward J., and Johnson K.: Well-to-Wheels Greenhouse Gas Emissions and Petroleum Use for Mid-Size Light-Duty Vehicles (2013) DOE Program Record 13005.

18. Kaya Y.: Impact of Carbon Dioxide Emission Control on GNP Growth: Interpretations of Proposed Scenarios (IPCC Energy and Industry Subgroup, Response Strategies Working Group, Paris, 1990).

19. U.S. Energy Information Agency: Motor Vehicle Mileage, Fuel Consumption, and Fuel Economy (2015). Available at: http://www.eia.gov/totalenergy/ data/monthly/pdf/sec1_19.pdf (accessed: September 18, 2015).

20. U.S. Department of Energy: Alternative Fuels Data Center (2014). Available at: http://www.afdc.energy.gov/fuels/fuel_comparison_chart. pdf (accessed: September 18, 2015).

21. U.S. Department of Transportation: National Transportation Statistics (2015). Available at: http://www.rita.dot.gov/bts/sites/rita.dot.gov.bts/ files/publications/national_transportation_statistics/index.html (accessed: September 7, 2015).

22. Sovran G. and Blaser D.: Quantifying the Potential Impacts of Regenerative Braking on a Vehicle's Tractive-Fuel Consumption for the U.S., European, and Japanese Driving Schedules. SAE Technical Paper Series: Advanced Hybrid Vehicle Powertrains (SP-2008) 2006-01-0664 (2006).

23. Guzzella L. and Sciarretta A.: Vehicle Propulsion Systems: Introduction to Modeling and Optimization (Springer-Verlag, Berlin Heidelberg, 2005).

24. Simpson A.G. and Walker G.R.: A Parametric Analysis Technique for Design of a Fuel Cell and Hybrid-Electric Vehicles. SAE Technical Paper Series 2003-01-2300 (2003).

25. U.S. Environmental Protection Agency: Dynamometer Drive Schedules (2015). Available at: http://www3.epa.gov/nvfel/testing/dynamometer. htm (accessed: September 18, 2015).

26. U.S. Department of Energy: Where the Energy Goes: Gasoline Vehicles (2015). Available at: https://www.fueleconomy.gov/feg/atv.shtml (accessed: September 26, 2015).

27. Taub A.I., Krajewski P.E., Luo A.A., and Owens J.N.: The evolution of technology for materials processing over the last 50 years: the automotive example. JOM 59(2), 48-57 (2007).

28. Taub A.I.: Automotive materials: Technology trends and challenges in the 21st century. MRS Bull. 31, 1-48 (2006).

29. Lutsey N.: Review of technical literature and trends related to automobile mass-reduction technology (Prepared for California Air Resources Board by The UC Davis Institute of Transportation Studies, 2010) UCD-ITS-RR-10-10.

30. Brooke L.: The F-150's Aluminum Diet (2014). Available at http://www. nytimes.com/2014/01/12/automobiles/autoshow/the-f-150s-aluminumdiet.html?_r=0 (accessed: June 15, 2016).

31. Cole G.S. and Sherman A.M.: Lightweight materials for automotive applications. Mater. Charact. 35(1), 3-9 (1995).

32. Committee for the National Tire Efficiency Study of the Transportation Research Board: Tires and Passenger Vehicle Fuel Economy. TRB Special Report 286 (The National Acadamies, Washington, DC, 2006).

33. National Highway Traffic Safety Administration: NHTSA Tire Fuel Efficiency Consumer Information Program Development: Phase 2-Effects of Tire Rolling Resistance Levels on Traction, Treadwear, and Vehicle Fuel Economy (2009) NHTSA DOT HS 811154.

34. Pike E.: Opportunities to Improve Tire Energy Efficiency (2011) The International Council on Clean Transportation ICCT White Paper Number 13.

35. Hucho W-H. and Sovran G.: Aerodynamics of road vehicles. Annu. Rev. Fluid Mech. 25, 485-537 (1993).

36. Rugh J. and Farrington R.: Vehicle Ancillary Load Reduction Project Close-Out Report (2008) NREL NREL/TP-540-42454.

37. Davis S.C., Diegel S.W., Boundy R.G., and Moore S.: 2014 Vehicle Technologies Market Report (Oak Ridge National Laboratory, Oak Ridge, TN, 2015) ORNL/TM-2015/85.

38. Alger T.: Clean and Cool: Cooled EGR improves fuel economy and emissions in gasoline engines (2010). Available at http://www.swri. 
org/3pubs/ttoday/Summer10/PDFs/Clean-and-Cool.pdf. (accessed: June 15, 2016).

39. Duleep G.: Comparison of Vehicle Efficiency Technology Attributes and Synergy Estimates (2011) NREL NREL/SR-6A20-47806.

40. Colwell K.C.: Engine Stop-Start Systems on Nonhybrid Vehicles: Stop and Go All The Way: A hybrid staple trickles into normal cars with modest initial success (2011). Available at http://www.caranddriver.com/features/ engine-stop-start-systems-explained-tech-dept (accessed: December 15 2015)

41. Saxena S., Phadke A., and Gopal A.: Understanding the fuel savings potential from deploying hybrid cars in China. Applied Energy 113 1127-1133 (2014)

42. Ahman M.: Primary energy efficiency of alternative powertrains in vehicles. Energy 26, 973-989 (2001).

43. Cuddy M. and Wipke K.: Analysis of the Fuel Economy Benefits of Drivetrain Hybridization (SAE International Congress, Warrendale, PA, 1997) SAE 970289.

44. National Renewable Energy Laboratory: Hydrogen Fuel Cell Electric Vehicle Learning Demonstration Composit Data Product \#8 (2009). Available at http://www.nrel.gov/hydrogen/cdp_topic.html (accessed: December 12, 2015).

45. Thomas C.E.: Fuel cell and battery electric vehicles compared. Int. J. Hydrogen Energy 34(15), 6005-6020 (2009).

46. Green Car Congress: New Two-Speed Electric Vehicle Transmission For Improved Performance, Range and Battery Life (2009). Available at http://www.greencarcongress.com/2009/05/vocis-20090512.html (accessed: December 17, 2015).

47. Green Car Congress: GM Provides Technical Details of the Gen 2 Voltec Propulsion System used in the 2016 Volt (2015). Available at http://www. greencarcongress.com/2015/04/20150423-voltec.html (accessed: December 17, 2015).

48. Pesaran A.A., Markel T., Tataria H.S., and Howell D.: Battery requirements for plug-in hybrid electric vehicles: Analysis and rationale. In 23rd International Electric Vehicle Symposium, Anaheim, California, December 2-5, 2007.

49. Tamor M.A., Gearhart C., and Soto C.: A statistical approach to estimating acceptance of electric vehicles and electrification of personal transportation. Transport. Res. C-Emer. 26, 125-134 (2013).

50. Andress D., Nguyen T.D., and Das S.: Reducing GHG emissions in the United States' transportation sector. Energy Sustainable Dev. 15(2), 117-136 (2011).

51. Moomaw W., Burgherr P., Heath G., Lenzen M., Nyboer J., and Verbruggen A.: Annex II: Methodology. In IPCC Special Report on Renewable Energy Sources and Climate Change Mitigation. Edenhofer O., Pichs-Madruga R., Sokona Y., Seyboth K., Matschoss P., Kadner S., Zwickel T., Eickemeier P., Hansen G., Schlömer S., and Stechow C.V. eds.; Cambridge University Press: Cambridge, United Kingdom and New York, NY, USA, 2011.

52. U.S. Energy Information Agency: How much gasoline does the United States consume? (2015). Available at http://www.eia.gov/tools/faqs/faq. cfm?id=23\&t=10 (accessed: October 12, 2015).

53. Argonne National Laboratory: Argonne GREET Model (2015). Available at https://greet.es.anl.gov (accessed: December 8, 2015).

54. DeCicco J.M.: Biofuel's carbon balance: Doubts, certainties and implications. Clim. Change 121(4), 801-814 (2013).

55. Joseck F. and Ward J.: Cradle to Grave Lifecycle Analysis of Vehicle and Fuel Pathways (2014). DOE hydrogen and fuel cells Program Record 14006.
56. Wang M., Wu M., and Huo H.: Life-cycle energy and greenhouse gas emission impacts of different corn ethanol plant types. Environ. Res. Lett. 2,13 (2007)

57. U.S. Department of Energy: Ethanol Feedstocks (2015). Available at http:// www.afdc.energy.gov/fuels/ethanol_feedstocks.html (accessed: October 19, 2015).

58. Milbrandt A.: A Geographic Perspective on the Current Biomass Resource Availability in the United States (2005). NREL NREL/TP-560-39181.

59. National Renewable Energy Laboratory: The Biofuels Atlas (2015). Available at https://maps.nrel.gov/biofuels-atlas/-/?aL=yilN7K\%255Bv\% 255D\%3Dt\%26yilN7K\%255Bd\%255D\%3D1\&bL= $\operatorname{groad} \& c E=0 \& 1 R=0 \&$ $\mathrm{mC}=40.21244 \% 2 \mathrm{C}-91.625976 \& \mathrm{zL}=4$ (accessed: October 19, 2015).

60. U.S. Department of Energy: U.S. Billion-Ton Update: Biomass Supply for a Bioenergy and Bioproducts Industry. Perlack R.D. and Stokes B.J. (Leads). ORNL/TM-2011/224 Oak Ridge National Laboratory: Oak Ridge, TN, $2011 ; 227$ p.

61. Gross B.K., Sutherland I.J., and Mooiweer H.: Hydrogen Fueling Infrastructure Assessment (2007). General Motors Corportation GM R\&D Report 11065.

62. Melaina M., Penev M., and Heimiller D.: Resource Assessment for Hydrogen Production: Hydrogen Production Potential from Fossil and Renewable Energy Resources (2013). NREL NREL/TP-5400-55626.

63. U.S. Department of Energy EERE: 2014 Renewable Energy Data Book (2015). DOE/GO-102015-4724.

64. U.S. Environmental Protection Agency: eGRID2012 (2015). Available at http://www.epa.gov/energy/egrid. (accessed: December 19, 2015).

65. Transportation Research Board and National Research Council: Overcoming Barriers to Deployment of Plug-in Electric Vehicles (The National Academies Press. Washington, DC, 2015) doi: 10.17226/21725.

66. Gearhart C., Gonder J., and Markel T.: Connectivy and Convergence: Transportation for the 21st Century. In IEEE Electrification Magazine (IEEE Power and Energy Society, Piscataway, NJ, 2014).

67. Brown A., Gonder J., and Repac B.: An analysis of possible energy impacts of automated vehicles. In Road Vehicle Automation. Meyer G. and Beiker S. eds.; Springer International Publishing: Switzerland, 2014; pp. 137-153.

68. MacKenzie D., Wadud Z., and Leiby P.: A first order estimate of energy impacts of automated vehicles in the United States. In 2014 TRB Annual Meeting, Washington, DC, 2014.

69. Anderson J.M., Kalra N., Stanley K.D., Sorensen P., Samaras C., and Oluwatola O.A.: Autonomous Vehicle Technology: A Guide for Policymakers (2014) Rand: Transportation, Space, and Technology Program.

70. OECD International Transport Forum: Urban Mobility System Upgrade: How shared self-driving cars could change city traffic (International Transportation Forum, Paris, France, 2015).

71. Barcham R.: Climate and Energy Impacts of Automated Vehicles. (Prepared for the California Air Resources Board by the Goldman School of Public Policy, University of California, Berkeley, Berkeley, CA, 2014).

72. Gonder J., Earleywine M., and Sparks W.: Analyzing vehicle fuel saving opportunities through intelligent driver feedback. SAE International Journal of Passenger cars-Electronic and electrical systems 5(2), 450-461 (2012).

73. Greenblatt J.B. and Saxena S.: Autonomous taxis could greatly reduce greenhouse-gas emissions of US light-duty vehicles. Nat. Clim. Change $5(9), 860-863$ (2015)

74. Gonder J., Wood E., and Rajagopalan S.: Connectivity-enhanced route selection and adaptive control for the Chevrolet Volt. In 21 st world Congress on Intelligent Transport systems 2014. Detroit, Michigan September 7-11, 2014. (National Renewable Energy Laboratory, Golden, CO, 2014). NREL/ CP-5400-60960. 